\title{
The mission of the Catholic school and the preferential option for the poor
}

\author{
Stephen McKinney
}

\section{Introduction}

Two interconnected themes in the research of Gerald Grace are the mission of the Catholic school and the preferential option for the poor. Grace is anxious to connect these themes conceptually but also in the operation and daily life in Catholic schools. This can be discerned in the seminal Catholic Schools: Mission, Markets and Morality (2002) and the International Handbook of Catholic Education: Challenges for School Systems in the 21st Century (2007) and also in articles in the Oxford Review of Education (2001), International Studies in Sociology of Education (2003) and International Studies in Catholic Education (2013). This chapter examines the conceptual and practical connections between these two themes in the works of Grace and deepens and expands the discussion, drawing on scripture, theology and some key Church documents on Catholic education and schooling. The chapter argues that these two themes are key to an understanding of the authentic mission and role of Catholic schools in the 21st century, in the United Kingdom and internationally.

\section{The preferential option for the poor in the works of Professor Gerald Grace}

Professor Gerald Grace is a great advocate of the idea and practice of the preferential option for the poor in Catholic schools. He has consistently highlighted this issue in his lectures and has adopted a number of approaches to the issue in his publications and as editor of International Studies in Catholic Education. These approaches are interconnected, but it is instructive to separate them and provide a brief examination of each one.

First, he draws on the history of Catholic schools in England and Wales and the legacy of the 'mission' to the poor. This is exemplified in The State and Catholic Schooling in England and Wales: Politics, Ideology and Mission Integrity (2001) where he discusses the priority of Catholic school education over other work in the Catholic Church in England and Wales in the 19th century. The renewal of the Catholic faith depended upon good Catholic schooling in the view of the bishops.

DOI: $10.4324 / 9781003171553-19$ 
Second, he argues that the preferential option for the poor is an integral part of the aim and mission of the contemporary Catholic school (Grace, 2002, 2003; Grace and O'Keefe, 2007). In a number of publications, he illustrates this by highlighting sections of The Catholic School document (1977), especially section 58 (see Grace, 2000, 2003, 2009; Grace and O'Keefe, 2007). ${ }^{1}$ The highlighted part of section 58 comments:

...first and foremost the Church offers its educational service to "the poor or those who are deprived of family help and affection or those who are far from the faith". Since education is an important means of improving the social and economic condition of the individual and of peoples, if the Catholic school were to turn its attention exclusively or predominantly to those from the wealthier social classes, it could be contributing towards maintaining their privileged position, and could thereby continue to favour a society which is unjust.

(The Sacred Congregation for Catholic Education, 1977, section 58)

Third, he uses the idea of the preferential option of the poor as a lens in his analysis of the theological and ecclesial integrity of the stated mission and coherence in practice in contemporary Catholic schools in England. This is observed in Catholic Schools: Mission, Markets and Morality (2002). This lens is extended to Catholic schools in other parts of the world in the International Handbook of Catholic Education: Challenges for School Systems in the 21st Century (2007) co-edited with J. O'Keefe. Grace and O'Keefe list the challenges that Catholic schools face in the 21st century in the introduction. One challenge is 'Responding to Vatican II principles of renewal of the mission e.g. with special reference to the "preferential option for the poor" (p. 2). They invited the contributors to the International Handbook to report on how Catholic school systems respond to the preferential option for the poor in their national contexts. Grace and O'Keefe $(2007$, pp. 6, 9) are acutely aware of the complexities of funding for Catholic schooling throughout the world and they warn of the dangers of the selection of children for Catholic schools on the grounds of wealth or ability to the exclusion of other children:

Catholic schooling internationally will be faced with a major contradiction if, despite a formal commitment to the service of the poor, it is found in practice to be largely in the service of students from more favoured sectors of society.

(Grace and O'Keefe, 2007, p. 6)

This is consistent with the message of section 58 of The Catholic School (1977) quoted above.

Fourth, Professor Grace positions the preferential option for the poor within the wider discussion of Catholic Social Teaching (CST). He argues that CST should permeate the curriculum of the Catholic school and not be confined to 
the Religious Education classroom (Grace, 2013). This argument is supported by a close reading of Pope Benedict's Caritas in Veritate (2009) and includes a concerted focus on inequalities in wealth and resources and the possibilities of large-scale redistribution of wealth (Grace, 2013, pp. 102-103).

Fifth, he has been very proactive in promoting research into the preferential option for the poor and Catholic schools. He has consistently published articles focussed on this topic as editor of International Studies in Catholic Education (first issue in 2009). This can be discerned in Klaiber (2013) and Wodon (2020). This extends to publishing articles on Liberation Theology per se and CST and Catholic education (Torevell, 2013; Byron, 2015; Madero, 2018).

The contribution of Professor Grace to the promotion of the preferential option for the poor has been invaluable and has demonstrated a powerful and unswerving dedication to this fundamental principle. His concern for the preferential option for the poor is within the context of a deep understanding of the complexities of the relation between the Church and Catholic schools and the State and the competing demands on Catholic schools (Grace, 2001). This includes the aforementioned pressures of securing funding for Catholic schools and of the academic competition between schools that is driven by the neo-liberal marketisation of education. He has consistently warned of the dangers of the preferential option for the poor being a low priority or even being ignored, echoing the concerns raised about Catholic educational institutions straying from the preferential option for the poor in Consecrated Persons and their Mission in Schools: Reflections and Guidelines (Congregation for Catholic Education, 2002, sections 70, 75).

\section{Liberation Theology and the preferential option for the poor}

Poverty is a human question, a Christian question-because poverty is death; it is inhuman; it is anti-evangelical. Theologians, among them my friends, will say, "I know you are very concerned with poverty because you are a Peruvian.” I reply, "No, my friend, I am concerned because I am Christian."

(Gutiérrez, 2012, pp. 5-6)

The term 'preferential option for the poor' originates in the early development of Liberation Theology. Liberation Theology emerged in the 1960s in Latin America as a response to the crippling poverty and the unjust social structures experienced by many people. There are a number of key figures associated with the rise and development of Liberation Theology in the Catholic Church, including: Jon Sobrino SJ; Leonardo Boff; Clodovis Boff; Juan Luis Segundo SJ and Gustavo Gutiérrez. Gutiérrez is the theologian most closely associated with the emergence of Liberation Theology and continues to be a powerful advocate of Liberation Theology.

The writings of Gutiérrez have been heavily critiqued: for using Marxist analysis as a scientific tool; for the use of dependency theory, especially in early 
works; and for being 'contextual' theology (Houtart, 1989; Groody, 2011). ${ }^{2}$ Critics of Gutiérrez often focus on his early work, fail to discern the developments in his theology and fail to acknowledge that he has always positioned himself firmly within the Catholic Church. Gutiérrez used dependency theory in a qualified and critical manner, fully aware of the limitations of the theory and anxious about an over-emphasis on external factors and not enough on internal factors (McGovern, 1989). Gutiérrez proposed that some aspects of Marxist analysis could be used as a 'science', as an analytical tool, and not as an ideology in Theology of Liberation. While his use of Marxist-related analysis has been arguably exaggerated, his later theology has moved away from the use of this analysis. Liberation Theology has been categorised and almost dismissed as 'contextual theology'. Gutiérrez (2012) counter-argues that all theology is contextual. Theology should be engaged with the problems of the current context in the contemporary world. Further, Gutiérrez emphasises that the theologian is called to discipleship, like every other believer (Gutiérrez 1996). Nolan (1989) comments that Gutiérrez is considered to be a modern-day prophet because he speaks of God to the present-day context: 'All prophecy and prophetic theology speaks of, and speaks to, a particular time in a particular place about a particular situation' (Nolan, 1989, p. 433).

In recent years, there appears to have been a decline in interest in Latin American and Caribbean Liberation Theology (Müller, 2015). This is disappointing as there is much to be gained from academic and ecclesial appraisal of the contribution of Liberation Theology and its influence on Church teaching and Catholic education. The works of Gutiérrez, in particular, provide deep insights into the preferential option for the poor and its roots in the gospels. Gutiérrez argues:

The fundamental contribution of liberation theology, it seems to me, revolves around what is called the 'preferential option for the poor' ... The option for the poor is radically rooted in the gospel and this constitutes an important guideline for sifting through the fast-paced events and the intellectual currents of our days.

(Gutiérrez, 2015, p. 88)

Gutiérrez has spent his life trying to talk about the love of God in 'a situation characterised by poverty and oppression' (Gutiérrez, 1989, p. xiv). The preferential option for the poor is rooted in the gratuitousness of God's love (Gutiérrez, 1996). The word 'preference' is not a negation of the universality of God's love because 'preference' does not mean that God's love for the poor is exclusive. Rather, the word preference stresses that the poor are the first, not the only persons, to receive the love of God, and it is this preference that Christians are called to follow by Jesus Christ (Matthew 11:5; Luke 4: 16-22; Gutiérrez, 1983, 2009). Gutiérrez (2012) argues that it is not enough if we are in solidarity with the poor and are critical of the causes of poverty; we have to fight against the causes of poverty. 


\section{The scriptural roots of the preferential option for the poor}

This contemporary articulation of the 'preferential option for the poor' is drawn from fundamental principles in the Old and New Testaments. These begin with the God-given dignity of all people who are made in the image of God (Genesis 1:27). ${ }^{3}$ The obligation to care for the widow, the orphan, the stranger in the Old Testament is mandated by God in the Holiness Code in the book of Leviticus $(19: 9-10 ; 23: 22)$ and the book of Exodus $(22: 20-23 ; 23: 9)$. The gospels provide many examples of the preference for the poor, notably in the Magnificat (Luke 1:46-55), Jesus in the synagogue (Luke 4:16-22), the parable of the Good Samaritan (Luke 10:25-37), the Beatitudes and curses (6:20-26); right use of possessions (Luke 12:13-21, 12:33-34. 14:33) and the Last Judgement in Matthew 25 (31-46). I have explored some of the major sources for the preference for the poor in the Old Testament and in Luke's gospel in other works (McKinney, 2018a, 2018b, 2018c). I now turn to further important sources. The first is a series of four key passages from the Acts of the Apostles that examine events in the early Christian community in Jerusalem. The second is a passage from Matthew's gospel and is usually called 'The Last Judgement' or 'The Sheep and the Goats'.

\section{The Acts of the Apostles}

Let us examine four key passages from the Acts of the Apostles that focus on the early Christian community and the care for the poor. The first two passages are Acts 2:42-47 and Acts 4:32-35. Acts 2:42-47 depict the early Christian community in Jerusalem that adhered to the teaching of the Apostles, lived in harmony, prayed (see also Acts 1:14) and celebrated the Lord's Supper (Fitzmyer, 1998). ${ }^{4}$ The community is described as follows: 'The faithful all lived together and owned everything in common; they sold their goods and possessions and shared out the proceeds among themselves according to what each one needed' (Acts 2:44-45).

This may be an idealised account of the early Christian community but one that Luke wished to emphasise (Barrett, 2002, p. 34). This is revisited in Acts:

The whole group of believers was united, heart and soul; no one claimed for his own use anything that he had, as everything they owned was in common... None of their members was ever in want, all those who owned land or houses would sell them, and bring the money from them, to present it to the apostles; it was then distributed to any members who might be in need.

(Acts 4:32, 34-35)

This passage is immediately preceded by the accounts of Barnabas (4:36-37) and Ananias and Sapphira (5:1-11). Barnabas owned a piece of land, sold it and brought the money to the Apostles, acting in accordance with the 
representation of the community in Acts 2:42-47 and Acts 4:32-37. The story of Ananias and his wife Sapphira is one of deception and represents a fracture in the community. Ananias agreed to sell a property but held some of the money back, with the connivance of his wife. When challenged by Peter, Ananias falls down dead to the ground. Later Peter challenges Sapphira, who tries to deceive Peter about the price of the property and she too falls down dead to the ground. These two very dramatic episodes of miraculous intervention may have antecedents in examples of punitive deaths in the Old Testament, but ultimately, they serve to demonstrate that the communal life has been disrupted by evil and deception (Fitzmyer, 1998, p. 320; Harrill, 2011; O'Loughlin, 2014).

The story of Ananias and Sapphira is not couched as a direct teaching on the dangers of avarice and the renunciation of possessions that can be found in the Luke's gospel (12:13-34; 16:1-31; 18:18-30; 19:1-10; Tannehill, 2012, p. 280). Nevertheless, Luke has once again highlighted the importance of the right use of material possessions and the dangers of the wrong attitude towards money and, in this case, money that was to be used to help the poor in the community.

The final passage from Acts is Acts 6:1-6. The passage recounts another serious disruption to the harmony of the community: 'About this time, when the number of disciples was increasing, the Hellenists made a complaint against the Hebrews: in the daily distribution their own widows were being overlooked' (Acts 6:1).

The distribution of food was no longer 'according to what each one needed' as described in Acts 2:44-45. The Twelve act quickly and seven men were appointed to give out the food $(6: 2-6)$. This lack of care appears to be a form of double discrimination. It discriminates against the Hellenists (non-Jewish Christians) and widows (some of the most vulnerable people in the community). This lack of care of the widows recalls the many times the Jews were reminded of their duty to care for the widows in the Old Testament (Fitzmyer, 1998 , p. 345). Possibly the role of the Seven in waiting on the tables was to reemphasise the importance of using table fellowship to welcome the outsider, the outcast - as Jesus had done (Luke 5:29-32; 15:1-2; Pao, 2011. p. 139). The idyllic Christian life as presented in Acts chapters 2 and 4 has been disrupted by deception and exclusion. The exclusion of the widows is only resolved by swift and decisive intervention.

\section{Matthew 25:3 I-46: The Last Judgement - the Sheep and the Goats}

The passage in Matthew's gospel refers to the Last Judgement and the separation of people as a shepherd separates sheep from goats, according to their care for the hungry, the thirsty, the stranger, the naked, the sick and the prisoner. The virtuous, the sheep, enter into the kingdom because they have cared for the needy and by doing so have demonstrated their care for God. The goats have not attended to the needs of these others and are to be treated harshly: 
Next he will say to those on his left hand, 'Go away from me, with your curse upon you, to the eternal fire prepared for the devil and his angels. For I was hungry and you never gave me food; I was thirsty and you never gave me anything to drink; I was a stranger and you never made me welcome, naked and you never clothed me, sick and in prison and you never visited me.' Then it will be their turn to ask, 'Lord, when did we see you hungry or thirsty, a stranger or naked, sick or in prison, and did not come to your help?' Then he will answer, 'I tell you solemnly, in so far as you neglected to do this to one of the least of these, you neglected to do it to me'. And they will go away to eternal punishment, and the virtuous to eternal life.

The Last Judgment in Matthew 25:31-46 is a passage that Gutiérrez has referred to frequently in his writings (Gutiérrez, 1971, 1991, 1992, 2012). He interprets this passage in a number of ways and is influenced by the writing of Bartolomé de Las Casas (1484-1566), especially De Unico Modo (1537), and Pope John Paul II (Gutiérrez, 1992, 1996)..$^{5}$ First, he recognises the core message of the passage: 'In Matthew 25:31-46, Jesus speaks of the last judgment and says if we give food to the least of our siblings, we give food to him. This is a very bold affirmation of the gospel writer' (Gutiérrez, 2012, p. 8).

Gutiérrez does not understand this in an allegorical manner nor in a 'spiritualizing manner'; he understands the passage as an insistence on the need for "concrete, "material" actions towards others and especially the poor' (Gutiérrez, 1991, p. 119). Christian disciples are called to witness through these kinds of concrete actions (p. 131). This is the active discipleship of the sheep, the virtuous, in the passage and not the passivity of the goats (Carter, 2007, p. 92).

Second, Gutiérrez presents an incisive and challenging interpretation of the latter part of the passage by quoting two sources. Gutierrez explains that de Las Casas drew on this passage to vehemently denounce the injustice enacted towards the indigenous people of the Indies in De Unico:

Bartolomé returns to this Gospel passage, recalling a penetrating question posed by Augustine of Hippo: "If someone is damned by hellfire by Christ saying to him or her: 'I was naked and you did not clothe me,' to what hellfire will they be damned to whom he says, 'I was clothed and you stripped me!'” That is what is actually going on in the Indies. Not only are the naked not clothed, but, perversely, the poor of those lands are violently unclothed: the Indians are despoiled of their legitimate possession. The poor are robbed and, in them, Christ himself.

(Gutiérrez, 1992, p. 64)

In a later work, Gutiérrez (1996) draws on the homily delivered by Pope John Paul II in Edmonton airport in Canada in 1984. Similar to de Las Casas, John Paul II explores some of the deeper implications of the Last Judgement in 
Matthew 25: 31-46. He applies the words of Jesus to the global injustice that exists between the rich north and the poor south:

Nevertheless, in the light of Christ's words, this poor South will judge the rich North. And the poor people and poor nations - poor in different ways, not only lacking food, but also deprived of freedom and other human rights - will judge those people who take these goods away from them, amassing to themselves the imperialistic monopoly of economic and political supremacy at the expense of others.

(Pope John Paul II, 1984, section 4)

The preferential option for the poor, the fundamental contribution of Liberation Theology, is a powerful demand for justice in the world. It is at the heart of Christianity and Christian life and cannot be reduced to pious sentiments; it requires different forms of action: solidarity with the poor and fighting the effects and causes of poverty.

\section{Catholic schools}

The history of contemporary Catholic schools in the United Kingdom commences in the late 18th and early 19th centuries and is closely connected to the historical development of the Catholic Church. ${ }^{6}$ Some of the prominent features of this history include (1) the arrival of Catholic migrants from Ireland in the 19th and 20th centuries and, at different times, Catholic migrants from Italy, Poland, Belgium, Ukraine and Lithuania and (2) the low socio-economic status of many in the Catholic population (Tenbus, 2010; Taylor, 2018). ${ }^{7}$ The mission to the poor Catholic children was part of the rationale for the establishment and growth of Catholic schools. Historians recognise the role of the Religious Orders and Congregations in providing high-quality school education, notably in the advanced stages of schooling (McKinney and McCluskey, 2019). This facilitated opportunities to acquire public examination qualifications and increased the possibility of economic advancement and social mobility.

The scourge of poverty, however, remains very real in the United Kingdom and still affects children in schools. Child poverty remains a serious challenge for society and schools have limited resources to address this challenge. Many teachers work with children who suffer from the effects of poverty on a daily basis. The language of 'mission to the poor' in Catholic schools has evolved into 'preferential option for the poor', 'inclusion' and the education of the 'most vulnerable'.

I have previously highlighted the importance of the Vatican document Consecrated Persons and their Mission in Schools: Reflections and Guidelines (2002) because of the depth of the detail of the theological discussion on poverty and Catholic education (McKinney, 2018a, 2018b, 2018c). This document captures a real sense of the prophetic vision of the preferential option for the poor in 
Catholic schools. One of the key statements is that 'The preferential option for the poor leads to avoiding all forms of exclusion' (section 69). This is further developed in the challenge of positioning the poorest at the centre of the educational endeavour:

When the preferential option for the poorest is at the centre of the educational programme, the best resources and most qualified persons are initially placed at the service of the least, without in this way excluding those who have less difficulties and shortages. This is the meaning of evangelical inclusion, so distant from the logic of the world. The Church does, in fact, mean to offer its educational service in the first place to "those who are poor in the goods of this world or who are deprived of the assistance and affection of a family or who are strangers to the gift of Faith."

(Section 70)

This passage extends section 58 of The Catholic School (1977). ${ }^{8}$ This prophetic vision of the preferential option for the poor needs to be exemplified in examples of concrete witness and action. I present two case studies of concrete preferential option for the poor below, both located in Catholic schools in Scotland.

\section{Case study I}

Case study 1 is focussed on John Ogilvie High School, a State-funded Catholic secondary school in South Lanarkshire. This Catholic school was anxious to include an increasing number of new-arrival Polish children in the life of the school (McKinney et al., 2015). The children belonged to families that had migrated to the area to work in local industries. These families were mostly at the lower end of the socio-economic scale. The school faced challenges of engaging with children with little knowledge of the English language and Scottish culture and sought the support of the Scottish research team from the European Portfolio of Integration Project. The Portfolio of Integration was designed in Italy to help new-arrival children integrate into school education and community life. The head teacher of John Ogilvie High School approached neighbouring schools to participate in specially designed training sessions. The research team identified three ways in which John Ogilvie High School and the other schools were meeting the challenges: addressing language; creating culturally relevant pedagogy and pastoral support.

John Ogilvie High School was acutely aware that the language and culture of the new-arrival Polish children were not simply to be accommodated but valued. The staff were trained in some basic Polish and school signs were bilingual. The school aimed to respect Polish traditions and celebrated Polish feasts where appropriate. It worked with parents in a home school partnership. In effect, the school made changes in the way it operated to integrate these 
young people within the school. The aim was to ensure that the dignity of the Polish children was respected, that they felt fully accepted and did not feel marginalised in the school. This was a form of the 'evangelical inclusion' advocated by Consecrated Persons and their Mission in Schools: Reflections and Guidelines (2002, section 70).

\section{Case study 2}

Case study 2 is focussed on Trinity High School, also a State-funded Catholic secondary school in South Lanarkshire. The school established a 'Nurture Group' in 2009 to provide support for the most vulnerable young people in the school (McKinney and Hall, 2016). The Nurture Group targets young people who have experienced severe social, emotional and behavioural challenges. This includes poverty and disadvantage, trauma, deep emotional upset, experience of abuse, violence and neglect (Chapman et al., 2015). These are young people who make slow academic progress, can exhibit behavioural difficulties, and are at risk of suspension or exclusion. The Nurture Group provides support to the young people in the form of a designated and carefully furnished space and selected teaching staff who have been trained to provide pastoral care. The young people begin the school day in the Nurture room and prepare for the school day. The group also depends on the cooperation of the teaching staff throughout the school, as the young people can return to the Nurture room at any point in the day if they feel undue stress in a class. The Nurture Group has been very successful in actively supporting the young people, integrating them into the school and in helping them to progress to an initial positive leaver destination at the end of formal schooling.

The school has placed the most vulnerable young people at the centre of the educational programme by providing the special support that is required by these young people. The school has made decisions about allocating significant professional and material resource to support these young people and, by doing so, acts in solidarity with the poor and the most vulnerable, the ones who could be excluded or self-exclude. This ensures that these young people remain included in the life of the Catholic school.

\section{Conclusion}

The concept and enactment of the preferential option for the poor in Catholic schools draws from the fundamental principle of the scriptures of the care for the poor and the marginalised. The message of care is quite clear, and the poor must not be excluded. The two case studies have provided two quite different examples of Catholic schools resolving to enact the preferential option for the poor in the daily life of the school. This is based on conscious and courageous decisions that are coherent with the Christian vision of the dignity of all individuals and the inclusion of all. 
At the time of completing this chapter (November 2020), the world is still experiencing the effects of the Covid-19 pandemic and the subsequent series of restrictions and lockdowns. These restrictions and lockdowns have created very serious challenges for the poor in Catholic schools that include higher levels of food insecurity, digital exclusion and issues of physical and mental health and wellbeing (McKinney, 2020). We are witnessing increased levels of poverty and child poverty across the world and this will have a long-term effect on families, children and school education in the United Kingdom. It is important to be clear that the levels of poverty and child poverty were increasing before the pandemic and the lockdowns as a result of a number of factors: the changes in benefits and the introduction of Universal Credit and the increase in working poverty (McKinney et al., 2020). The pandemic, lockdowns and restrictions have extended and deepened the effects of the pre-existing poverty that was affecting increasing numbers of families. The prophetic Christian mandate of the preferential option for the poor is now more urgent than ever for children in Catholic schools.

\section{Notes}

1 Section 58 expands on an initial statement on caring for the poor in section 9 in Gravissimum Educationis (Pope Paul VI, 1965). The poverty experienced by the children is: '...poor in the goods of this world or who are deprived of the assistance and affection of a family or who are strangers to the gift of Faith' (Pope Paul VI, 1965).

2 Gutiérrez has been critiqued for selective use of scripture. For a discussion of his use of scripture and an extended examination of his use of Marxist analysis, see McKinney, S.J. (2021).

3 Compendium of the Social Doctrine of the Church, section 108 (Pontifical Council for Justice and Peace, 2004).

4 The Franciscan Peter John Olivi (1248-1298) interpreted Acts 2:42-47 and 4:32-35 within the context of his mission to renew the Franciscan commitment to poverty (Karris and Flood, 2007).

5 Bartolomé de las Casas was a Spanish Dominican priest who worked as a missionary. He became a strong defender of the poor Indians who were part of the Spanish colonies and who were deemed to be less civilised. He was an outspoken critic of slavery and later became the bishop of Chiapa in Mexico. See Gutiérrez (1992).

6 The growth and development of the Catholic Church in the United Kingdom from the 19th century to the present day is complex and has been examined using a variety of hermeneutical lenses constructed around different forms of exclusion, including: antiCatholicism, sectarianism and socio-economic exclusion (Gheeraert-Graffeuille and Vaughan, 2020).

7 While the influx of the Catholic Irish was to have a major impact on Catholicism in the United Kingdom, it is important to recognise all Catholic migrant groups alongside the surviving Catholic communities in parts of the Highland and Islands of Scotland, old English Catholic gentry and the different waves of the influential Oxford movement in England. See Tenbus (2010) for some of the groups in England.

8 The document includes a very valuable discussion on the causes and manifestations of child poverty. Among these, destitution occupies an undisputable place. It often brings with it the lack of a family and of health, social maladjustment, loss of human dignity, impossibility of access to culture and consequently a deep spiritual poverty (Congregation for Catholic Education, 2002, section 71). 


\section{References}

Barrett, C.K. (2002). The Acts of the Apostles: A Shorter Commentary. Edinburgh: T \&T Clark.

Byron, W.J. (2015). What Catholic schools can do about world hunger. International Studies in Catholic Education 7 (2) pp. 201-209.

Carter, W. (2007) The Gospel of Matthew. In Segovia, F.F. and Sugirtharajah, R.S. (Eds.) A Postcolonial Commentary on the New Testament Writings. pp. 69-103. London: Bloomsbury.

Chapman, C., Lowden, K., Chestnutt, H., Hall, S., McKinney, S., Hulme, M. and Friel, N. (2015). The School Improvement Partnership Programme (2015): Using Collaboration and Enquiry to Tackle Educational Inequity. Report to Scottish Education, August 2015.

Congregation for Catholic Education (2002) Consecrated Persons and their Mission in Schools: Reflections and Guidelines. www.vatican.va/roman_curia/congregations/cca theduc/documents/rc_con_ccatheduc_doc_20021028_consecrated-persons_en.html.

de Las Casas, B. (1537) De Unico Vocationis Modo. Published in English as: Bartolomé de Las Casas: The Only Way. Edited by Helen Rand Parish. Translated by Francis Patrick Sullivan, S.J. Mahwah, NJ: Paulist Press, 1992.

Fitzmyer, J.A. (1998). The Acts of the Apostles. New York: Doubleday.

Grace, G. (2000). Catholic Schools and the Common Good: What This Means in Educational Practice. In Grace, G. (2016) Faith, Mission and Challenge in Catholic Education: The Selected Works of Gerald Grace. pp. 55-64. London: Routledge.

Grace, G. (2001). The State and Catholic schooling in England and Wales: politics, ideology and mission integrity. Oxford Review of Education 27 (4) pp. 489-500.

Grace, G. (2002). Catholic Schools: Mission, Markets and Morality. Oxford: Routledge Falmer.

Grace, G. (2003). 'First and foremost the Church offers its educational service to the poor': class, inequality and Catholic schooling in contemporary contexts. International Studies in Sociology of Education 13 (1) pp. 35-53.

Grace, G. (2009). On the International Study of Catholic Education. Why We Need More Systematic Scholarship and Research. In Grace, G. (2016) Faith, Mission and Challenge in Catholic Education: The Selected Works of Gerald Grace. pp. 114-124. London: Routledge.

Grace, G. (2013). Catholic social teaching should permeate the Catholic secondary school curriculum: an agenda for reform. International Studies in Catholic Education 5 (1) pp. 99-109.

Grace, G. and O'Keefe, J. (2007). (Eds.) International Handbook of Catholic Education: Challenges for School Systems in the 21st Century. Dordrecht: Springer.

Gheeraert-Graffeuille, C. and Vaughan, G. (2020). Anti-Catholicism in Britain and Ireland, 1600-2000: Practices, Representations and Ideas. London: Palgrave Macmillan.

Groody, D. G. (2011). Gustavo Gutiérrez: Spiritual Writings. New York: Orbis Books.

Gutiérrez, G. (1971). A Theology of Liberation. London: SCM Press.

Gutiérrez, G. (1983). We Drink from Our Own Wells. London: SCM Press Ltd.

Gutiérrez, G. (1989). On Job God-Talk and the Suffering of the Innocent. New York: Orbis.

Gutiérrez, G. (1991). The God of Life. Translated by Matthew J.O'Connell. Maryknoll, NY: Orbis Books. 
Gutiérrez, G. (1992). La Casas: In Search of the Poor of Jesus Christ. Translated by Robert Barr. New York: Orbis Books.

Gutiérrez, G. (1996). Where Will the Poor Sleep? In Gutiérrez, G. and Muller, G.L. (Eds.) (2015) On the Side of the Poor. The Theology of Liberation. pp. 83-133. Maryknoll, NY: Orbis Books.

Gutiérrez, G. (2009). The option for the poor arises from Faith in Christ. Theological Studies 70 pp. 317-326.

Gutiérrez, G. (2012). A Hermeneutic of Hope. The Center for Latin American Studies, Vanderbilt University - Occasional Paper No. 13.

Guitierrez, G. (2015). On the Side of the Poor: The Theology of Liberation. Maryknoll, New York: Orbis Books.

Harrill, J.A. (2011). Divine Judgment against Ananias and Sapphira (Act: 5:1-11): a stock scene of perjury and death. Journal of Biblical Literature 130 (2) pp. 351-369.

Houtart, F. (1989). Theoretical and institutional bases of the opposition to Liberation Theology. In Ellis, M.H. and Maduro, O. (Eds.) The Future of Liberation Theology: Essays in Honour of Gustavo Gutiérrez. pp. 261-271. New York: Orbis Books.

Karris, R.J. and Flood, D. (2007). Peter Olivi on the early Christian community (Acts 2:4247 and 4:32-35): the Christian way with temporalities. Franciscan Studies 65 pp. 251-280.

Klaiber, J. (2013). Fe y Alegría in Peru: solidarity and service in Catholic education. International Studies in Catholic Education 5 (2) pp. 144-160.

Madero, C. (2018). New thinking about Catholic education from Latin America: what the bishops said at Medellin (1968), Puebla (1979), Santo Domingo (1992), Aparecida (2007). International Studies in Catholic Education 10 (1) pp. 30-43.

McGovern, A.F. (1989) Dependency Theory, Marxist Analysis and Liberation Theology. In Ellis, M.H. and Maduro, O. (Eds.) The Future of Liberation Theology. Essays in Honour of Gustavo Gutiérrez. pp. 272-286. New York: Orbis Books.

McKinney, S.J. (2018a). The roots of the preferential option for the poor in Catholic schools in Luke's Gospel. International Studies in Catholic Education 10 (2) pp. 220-232.

McKinney, S.J. (2018b). The Preferential Option for the Poor and Catholic Schools. In Whittle, S. (Ed.) Researching Catholic Education: Contemporary Perspectives. pp. 95-112. Singapore: Springer.

McKinney, S.J. (2018c) Affirming the Place of Scripture in the Catholic School. In Whittle, S. (Ed.) Religious Education in Catholic Schools. pp. 173-192. Oxford: Peter Lang.

McKinney, S.J. (2020). Covid-19: food insecurity, digital exclusion and Catholic schools. Journal of Religious Education. Open Access at: https://link.springer.com/article/10. 1007/s40839-020-00112-8.

McKinney, S.J. (2021) Covid-19, Child Poverty, Catholic Schools and the Insights of Gustavo Gutiérrez. In Whittle, S. (Ed.) Irish and British Reflections on Catholic Education. Singapore: Springer.

McKinney, S.J. and Hall, S. (2016), Nurture groups - Inclusion of the most vulnerable children and young people in Catholic schools. The Pastoral Review 12 (4) pp. 28-33.

McKinney, S.J., Hall, S. and Lowden, K. (2020). Poverty and Education in Scotland. In Thompson, I. and Ivinson, G. (Eds.) Poverty in Education Across the UK: A Comparative Analysis of Policy and Place. pp. 65-88. Bristol: Policy Press.

McKinney, S.J., McAdam, J., Britton, A., Crichton, H. and Arizpe, E. (2015). Managing the Learning of New Arrival Children in Mainstream Schooling. In Christopher, E. (Ed.) International Management and Intercultural Communication: A Collection of Case Studies, Volume 2. pp. 114-131. London: Palgrave Macmillan. 
McKinney, S.J. and McCluskey, R. (2019) (Eds.) A History of Catholic Schooling and Education in Scotland: New Perspectives. London: Palgrave Macmillan.

Müller, G.L. (2015). Liberation Theology in Context. In Gutiérrez, G. and Muller, G.L. (Eds.) On the Side of the Poor. The Theology of Liberation. pp. 54-82. Maryknoll, NY: Orbis Books.

Nolan, A. (1989). Theology in a Prophetic Mode. In Ellis, M.H. and Maduro, O. (Eds.) The Future of Liberation Theology: Essays in Honour of Gustavo Gutiérrez. pp. 433-440. New York: Orbis Books.

O'Loughlin, T. (2014). Sharing food and breaking boundaries: reading of Acts 10-11: 18 as a key to Luke's ecumenical agenda in Acts. Transformation: An International Journal of Holistic Mission Studies 32 (1) pp. 27-37.

Pao, D.W. (2011). Waiters or preachers: Acts 6:1-7 and the Lukan table fellowship motif. Journal of Biblical Literature 130 (1) pp. 127-144.

Pontifical Council for Justice and Peace (2004). Compendium of the Social Doctrine of the Church. www.vatican.va/roman_curia/pontifical_councils/justpeace/documents/ rc_pc_justpeace_doc_20060526_compendio-dott-soc_en.html\#Creatures \%20in \%20the $\% 20$ image $\% 20$ of $\% 20$ God.

Pope Benedict XVI (2009). Caritas in Veritate. www.vatican.va/content/benedict-xvi/en/ encyclicals/documents/hf_ben-xvi_enc_20090629_caritas-in-veritate.html.

Pope John Paul II (1984). Homily delivered at Holy Mass at Edmonton Airport Canada, 17 September.https://w2.vatican.va/content/john-paul-ii/en/homilies/1984/documents/ hf_jp-ii_hom_19840917_messa-edmonton.html.

Pope Paul VI (1965). Gravissimum Educationis (Declaration on Christian Education). www. vatican.va/archive/hist_councils/ii_vatican_council/documents/vat-ii_decl_19651028_grav issimum-educationis_en.html.

Tannehill, R.C. (2012). Acts of the Apostles and ethics. Interpretation: A Journal of Bible and Theology 66 (3) pp. 270-282.

Taylor, R. (2018). The relief of Belgian refugees in the archdiocese of Glasgow during the First World War: 'A Crusade of Christianity'. The Innes Review 69 (2) pp. 147-164.

Tenbus, E.G. (2010). English Catholics and the Education of the Poor. Abingdon: Routledge.

The CTS New Catholic Bible (2007). London: Catholic Truth Society.

Sacred Congregation for Catholic Education (1977). The Catholic School. www.vatican.va/ roman_curia/congregations/ccatheduc/documents/rc_con_ccatheduc_doc_19770319_cath olic-school_en.html.

Torevell, D. (2013). Liberation, Catholic education and the nature of theology: an essay to assist Catholic teachers with problems in this field. International Studies in Catholic Education 5 (2) pp. 218-232.

Wodon, Q. (2020). How well do Catholic and other faith-based schools serve the poor? A study with special reference to Africa: Part II: learning. International Studies in Catholic Education 12 (1) pp. 3-20. 